\title{
Kebijakan Jogo Tonggo Pemerintah Provinsi Jawa Tengah dalam Penanganan Pandemi Covid-19
}

\author{
Kurnia Sulistiani ${ }^{1}$, Kaslam ${ }^{2}$ \\ Program Studi Politik dan Kewarganegaraan Universitas Negeri Semarang ${ }^{1}$ \\ Program Studi Hubungan Internasional Universitas Islam Negeri Alauddin Makassar ${ }^{2}$ \\ e-mail: kurniaalkhanzha@gmail.com ${ }^{1}$, etos.kaslam@uin-alauddin.ac.id ${ }^{2}$
}

\begin{abstract}
Abstrak
Coronavirus Disease 2019 (Covid-19) yang sedang terjadi saat ini merupakan permasalahan dunia. Hal ini dibuktikan dengan ditetapkannya Covid-19 sebagai Pandemi Global oleh WHO. Tujuan penelitian ini adalah mendekripsikan dan menganalisis kebijakan Gubernur Jawa Tengah dalam pencegahan dan penanganan Covid-19. Metode penelitian ini adalah kualitatif deskriptif. Pengumpulan data yang dilakukan melalui studi pustaka dan dokumentasi. Hasil penelitian menujukkan bahwa pemerintah Jawa Tengah telah menguarkan kebijakan Jogo Tonggo dalam menangani wabah Covid-19, namun faktanya hingga saat ini permasalahan belum terselesaikan dengan baik. Salah satu faktor penyebabnya adalah kurangnya kesadaran masyarakat terhadab bahaya wabah Covid-19, sehingga dibutuhkan beberapa tindakan seperti peningkatan kualitas anggota Jogo Tonggo, adanya evaluasi dan pemilihan media sosial.
\end{abstract}

Kata Kunci :

Covid-19, Jogo Tongo, Kebijakan Pemerintah, Jawa Tengah

\section{PENDAHULUAN}

Coronavirus merupakan sejenis virus yang sangat berbahaya berasal dari subfamily Orthocronavirinae pada keluarga Coronaviridae dengan Ordo Nidovirales. Pada virus ini dapat mengakibatkan terserangnya penyakit pada burung dan mamalia, termasuk manusia. Bagi manusia, coronavirus ini dapat menyebabkan infeksi pada saluran pernapasan mulai dari gejala ringan, misalnya flu, demam, hilangnya rasa pengecapan hingga badan menjadi lemas. Infeksi akan terus menjalar hingga membentuk penyakit-penyakit mematikan seperti SARS, MERS hingga Covid-19 yang saat ini sedang melanda penduduk dunia.

Pada kondisi sekarang ini, Covid-19 adalah suatu wabah yang tidak bisa dianggap sepele begitu saja. Jika kita melihat gejala-gejala yang ada, masyarakat umum akan menganggapnya hanya sebatas penyakit influenza dan demam biasa. Akan tetapi bagi dunia kedokteran, virus ini sangat berbahaya dan bahkan dapat mematikan dalam kurung waktu 
yang singkat serta jika penderita yang sembuh pun akan mengalami kerusakan organ pernafasan permanen dan fungsinya tidak normal lagi seperti semula. Perkembangan penularan virus ini sangat signifikan dan massif karena penyebarannya sudah mendunia dan menyebar keseluruh benua sehingga ditetapkan sebagai pandemi global oleh World Health Organization (WHO) pada tanggal 13 Maret 2020. Penyakit Covid-19 menjadi permasalahan dunia dan perlu adanya kerjasama antarnegara dalam penyelesaian bencana sosial ini.

Kasus pertama Covid-19 ini berawal dari kasus pneumonia di Kota Wuhan, Provinsi Hubei, China, yang terjadi pada tanggal 31 Desember 2019. Berdasarkan laporan dari WHO China Country Office, penyakit ini mirip dengan kasus pneumonia yang tidak diketahui asal muasalnya. Penyebaran penyakit Covid-19 ini dari hari ke hari semakin meningkat, jumlah orang yang terinfeksi mencapai puluhan hingga ratusan setiap harinya, tergantung jumlah tes yang dilakukan oleh setiap negara.

Di Indonesia, kasus Covid-19 baru terdeteksi pada tanggal 17 Maret 2020 yang awalnya terkonfirmasi ada dua orang yang terinfeksi karena memiliki riwayat perjalanan dari negara terjangkit. Kedua orang tersebut dinyatakan sebagai Pasien Dalam Pengawasan (PDP). Hari demi hari kemudian jumlah kasus Covid-19 di Indonesia terus mengalami peningkatan yang cukup tajam, hingga sekarang per 31 mei 2020 penambahan kasus Covid-19 perhari bisa mencapai 557 kasus yang terinfeksi Covid-19. Jumlah kasus Covid19 di Indonesia per 30 Mei positif 25.773 orang, sembuh 7.015 orang dan yang meninggal 1.573 orang. ${ }^{1}$

Penambahan kasus Covid-19 yang sudah tersebar di 34 provinsi yang ada di Indonesia ini, termasuk pula Provinsi Jawa Tengah yang menempati posisi ke-5 dengan jumlah kasus Covid-19 per $30 \mathrm{Mei}$ 2020 mencapai 1.434 kasus, 759 orang sembuh dan 97 orang meninggal. Sedangan jumlah Orang Dalam Pemantauan (ODP) terkait Covid-19 di Jawa Tengah mencapai 35.450. Hampir semua kabupaten di Provinsi Jawa Tengah tengah terpapar Covid-19 diantaranya adalah Kota Semarang 63 kasus, Magelang 77 kasus, Purworejo 37 kasus, Wonosobo 19 kasus, Banyumas 19 kasus, Purbalingga 25 kasus, Temanggung 26 kasus, Cilacap 20 kasus, Demak 18 kasus, Banjarnegara 24 kasus, Sukoharjo 12 kasus, Salatiga 24 kasus, Surakarta 8 kasus, Kudus 3 kasus, Brebes 26 kasus, Sragen 20 kasus, Karanganyar 6 kasus, Pemalang 5 kasus, Kebumen 6 kasus, Batang 19 kasus, Kabupaten Semarang 9 kasus, Boyolali 11 kasus, Blora 21 kasus, Kota Magelang 7 kasus, Pati 1 kasus positif dan ODP 73, Klaten positif 7 kasus dan 153 ODP, Grobogan 5 kasus, Tegal 2 kasus, Jepara 9 kasus, Pekalongan 5 kasus, Kota Pekalongan 4 kasus, Wonogiri 0 positif dan ODP 61 orang, Kendal 2 kasus, Rembang 2 kasus, Kota Tegal 0 positif dan ODP 10 oang. Dari semua kabupaten

\footnotetext{
${ }^{1}$ Gugus Tugas Percepatan Penanganan Covid19. "Data Sebaran" dalam https://covid19.go.id/ diakses 31 Mei 2020.
} 
di Provinsi Jawa Tengah Kabupaten Magelang menempati posisi pertama kabupaten yang terpapar Covid-19 terbanyak. $^{2}$

Dengan mengamati perkembangan kasus Covid-19 di setiap Kabupaten/Kota di Provinsi Jawa Tengah setiap harinya yang selalu mengalami peningkatan, maka dari itu perlu upaya untuk mengatasinya. Dalam hal ini, kebijakan-kebijakan apa saja yang telah dikeluarkan oleh Pemerintah Provinsi Jawa Tengah untuk mengatasi wabah Covid-19 ini. Salah satu kebijakan Pemerintah Jawa Tengah dalam mengatasi Covid-19 yaitu Jogo Tonggo. Peneliti bermaksud mendeskripsikan dan menganalisis kebijakan tersebut. Seberapa efektifkah dalam upayanya mencegah peningkatan kasus Covid-19 di Provinsi Jawa Tengah.

\section{KAJIAN PUSTAKA}

Lebih lanjut mengenai kebijakan Pemerintah Provinsi Jawah Tengah dalam menangani wabah Covid-19 dengan program Jogo Tonggo, berikut beberapa kajian Pustaka yang dapat membantu dalam memetakan kebijakan-kebijakan apa saja yang telah dan belum dijelaskan oleh penelitian-penelitian terdahulu.

Nur Rohim Yunus dan Annisa Rezki dalam artikelnya yang dimuat di Jurnal SALAM: Jurnal Sosial dan Budaya Syar'i

\footnotetext{
${ }^{2}$ Provinsi Jawa Tengah, "Sebaran Kasus COVID-19 Di Jawa Tengah" dalam https://corona.jatengprov.go.id/ diakses 30 Mei 2020 .
}

Fakultas Syariah dan Hukum, UIN Syarif Hidayatullah Jakarta, berjudul Kebijakan Pemberlakuan Lockdown sebagai Antisipasi dalam Penyebaran Corona Virus Covid-19 mengatakan bahwa Indonesia sudah mengalami situsi dan kondisi dimana kekhawatiran masyarakat terhadap Covid-19 sangat besar, oleh karena itu diperlukan kebijakan pemerintah untuk melakukan lockdown, sebagai upaya dalam memutus rantai penyebaran virus corona Covid-19. ${ }^{3}$ Di dalam artikel tersebut, dipaparkan perkembangan kasus Covid-19 di Indonesia yang terus meningkat tajam, kemudian mengarah pada upaya pemerintah dalam mengatasinya dengan cara mengeluarkan kebijakan tentang lockdown selama 14 hari. Selama lockdown, tentunya masyakarat diperhadapkan oleh berbagai masalah, dalam artikel ini dijelaskan pula dampak negatif dan positif diberlakukannya kebijakan lockdown tersebut.

Luki Sandra Amalia dalam artikelnya Menanti Kebijakan Ketahanan Pangan di Tengah Pandemi Covid-19 mengatakan bahwa kebijakan ketahanan pangan merupakan kunci dalam menghadapi pandemi Covid-19. Negara harus hadir dalam memenuhi kebutuhan pokok rakyatnya. Jika pemerintah lamban dalam mengambil keputusan di situasi darurat pandemic Covid-19, maka masyarakat akan menjadi korban. Dalam Menyusun

\footnotetext{
${ }^{3}$ Nur Rohim Yunus \& Annisa Rezki, "Kebijakan Pemberlakuan Lockdown sebagai Antisipasi dalam Penyebaran Corona Virus Covid19", Salam: Jurnal Sosial dan Budaya Syar-i, Vol. Vol. 7 No. 3 (2020), h. 227-238.
} 
kebijakan tentang ketahanan pangan, pemerintah harus melihat empat aspek, yaitu ketersediaan pangan, akses yang terjangkau, pemanfaatan makanan dan stabilitas pasokan. ${ }^{4}$

Abdullah Ramdhani dan Muhammad Ali Ramdhani dalam artikel jurnalnya mengatakan bahwa implementasi kebijakan publik sangat dipengaruhi oleh faktorfaktor, seperti aspek kewenangan, sumberdaya, komunikasi, dan disposisi. ${ }^{5}$ Dimensi- dimensi yang bisa dipergunakan untuk mengevaluasi pelaksanaan kebijakan-kebijakan pemerintah yaitu konsistensi, transparansi, akuntabilitas, keadilan, efektivitas, dan efisiensi. Sementara itu evaluasi pelaksanaan kebijakan juga sangat perlu dilakukan secara komprehensif dan menyeluruh, seperti evaluasi ex-ante, on-going, dan ex-post atas pelaksanaan kebijakan publik. Dalam melakukan inovasi dan kreativitas dalam pelayanan kebutuhan publik, dapat dilakukan dengan diskresi pelaksanaan kebijakan publik sepanjang tidak bertentangan dengan norma dan peraturan yang berlaku.

Dari beberapa kajian literatur di atas, yang menjadi pembeda dengan penelitian kami yaitu bahwa kebijakan publik yang kami angkat yaitu Joko Tonggo di Jawa Tengah

${ }^{4}$ Luki Sandra Amalia, "Menanti Kebijakan Ketahanan Pangan di Tengah Pandemi Covid19"dalam http://www.politik.lipi.go.id/kolom/ kolom-2/politik-nasional/1397-menanti-kebijakanketahanan-pangan-di-tengah-pandemi-Covid-19 diakses 30 Mei 2020.

${ }^{5}$ Abdullah Ramdhani \& Muhammad Ali Ramdhani, "Konsep Umum dalam Pelaksanaan Kebijakan Publik", Jurnal Publik, Vol. 11, No. 01 (2017), h. 1-12. merupakan kebijakan yang lebih mengerucut pada suatu wilayah. Kami lebih fokus dalam mengkaji sejauh mana keefektifan kebijakan pemerintah Jawah Tengah dalam menerapkan program Joko Tonggo.

\section{TINJAUAN TEORETIS}

\section{Kebijakan Publik}

Dalam mengatasi permasalahan serius yang terjadi pada suatu daerah, seperti bencana, musibah atau wabah, khususnya dalam pencegahan dan penanganan Covid19 maka diperlukan sebuah kebijakan dari pemerintah setempat. Kebijakan adalah suatu keputusan politis yang diambil dan dijalankan oleh pemerintah sebagai bagian dari sikap pemerintah untuk memecahkan sebuah persoalan publik. Keputusan yang diambil tersebut harus mempertimbangkan semua aspek dan menghitung resiko yang ditimbulkan. Sebuah kebijakan tidak akan terlepas dari keterlibatan seluruh stakeholder yang ada, baik masyarakat sebagai bagian yang terikat dalam hasil keputusan kebijakan hingga sampai pada tahap pemerintah sebagai badan pembuat kebijakan tersebut.

Menurut Rian Nugroho "kebijakan adalah setiap keputusan yang dibuat dan dirancang oleh negara, sebagai strategi dalam merealisasikan tujuan dari negara. Kebijakan publik merupakan strategi dalam mengantarkan masyarakat pada masa permulaan, memasuki masyarakat pada masa transisi, hingga menuju 
masyarakat yang dicita-citakan."6 Dalam hal ini, kebijakan yang dibuat oleh Negara merupakan salah satu kunci untuk menjadikan masyarakat yang makmur dan sejahtera sesuai tujuan negara.

Thomas R. Dye mendefinisikan bahwa kebijakan publik sebagai "is whatever government choose to do or not to do" (kebijakan merupakan pilihan-pilihan apapun oleh pemerintah, baik untuk melakukan sesuatu maupun untuk tidak melakukan sesuatu). ${ }^{7}$ Sedangkan pada yang berbeda Thomas R. Dye juga mengatakan bahwa kebijakan publik adalah segala sesuatu yang dikerjakan pemerintah, mengapa mereka melakukan, dan hasil yang membuat sebuah kehidupan bersama tampil berbeda. ${ }^{8}$ Dalam hal ini, pemerintah perlu hati-hati dalam menentukan suatu pilihan yang dianggap benar dalam menangani suatu permasalahan dalam masyarakat. Di satu sisi juga, pemerintah memiliki wewenang mengambil keputusan untuk membiarkan sebuah permasalahan. Namun dalam perkembangannya, definisi-definisi tentang kebijakan publik mengalami pembaruan oleh ilmuan ilmuan di bidang yang sama.

\section{Analisis Kebijakan}

William N. Dunn mengatakan bahwa yang dimaksud dengan analisis kebijakan adalah aktivitas intelektual dan praktis yang ditujukan untuk menciptakan, secara

${ }^{6}$ Riant Nugroho, Public Policy (Jakarta: PT Elex Media Komputindo, 2009).

${ }^{7}$ Budi Winarno, Kebijakan Publik: Teori dan Proses (Jakarta: Media Pressindo, 2007).

${ }^{8}$ Riant Nugroho, 2009, h. 93-101. kritis menilai, dan mengkomunikasikan pengetahuan tentang dan dalam proses kebijakan. Analisis kebijakan merupakan disiplin ilmu sosial terapan yang menggunakan berbagai metode pengkajian multilevel dalam konteks argumentasi dan debat politik untuk menciptakan dan secara kritis menilai dan mengkomunikasikan pengetahuan yang relevan dengan kebijakan publik. Analisis kebijakan adalah aktivitas intelektual yang dilakukan dalam proses politik. Analisis kebijakan tidak dimaksudkan menggantikan politik dan membangun elite teknokratis. Analisis kebijakan diletakkan pada konteks sistem kebijakan. ${ }^{9}$

Pandangan lain juga disampaikan oleh E.S Quade, yang dikutip oleh William N. Dunn, analisis kebijakan adalah suatu bentuk analisis yang menghasilkan dan menyajikan informasi sedemikian rupa sehingga dapat memberikan landasan dari para membuat kebijakan dalam membuat keputusan. ${ }^{10}$ Dengan demikian, informasi informasi yang terkumpul dari pihak stakeholder akan menjadi bahan dalam membuat kebijakan, kemudian informasi tersebut disajikan dalam bentuk yang terperinci sebagai landasan dalam memilih alternatif yang ada sebagai sebuah sebuah keputusan untuk diterapkan dalam masyarakat.

Dari beberapa definisi diatas, dapat dikatakan bahwa Analisis kebijakan

\footnotetext{
${ }^{9}$ Riant Nugroho, 2009, h. 269-270.

${ }^{10}$ William N. Dunn, Analisis Kebijakan Publik (Yogyakarta: Gajah Mada University Press, 2003),
} h. 95-96. 
adalah aktivitas intelektual dan praktis yang ditujukan untuk menciptakan, secara kritis menilai, dan mengkomunikasikan pengetahuan tentang dan dalam proses kebijakan publik baik secara formal maupun informal yang menghasilkan dan menyajikan informasi sedemikian rupa sehingga dapat memberikan landasan bagi para pembuat kebijakan dalam membuat keputusan.

Analisis kebijakan itu dapat dilakukan sebelum atau setelah kebijakan diimplementasikan, menurut William N. Dunn berpendapat bahwa prediksi secara khusus digunakan sebelum suatu tindakan diadopsi (ex ante), sedangkan deskripsi dan evaluasi lazimnya dilakukan setelah suatu tindakan berlangsung (ex post). Prediksi dan preskripsi berhubungan dengan masa depan, sementara deskripsi dan evaluasi berhubungan dengan masa lalu. $^{11}$

Penelitian yang kami lakukan mengacu pada Analisis retrospektif atau ex post, yaitu Analisis yang dilakukan setelah aksi kebijakan pemerintah dilaksanakan oleh pemerintah. Dalam hal ini, kebijakan jogo tonggo yang diterapkan oleh Pemerintah Jawah Tengah dalam menangani kasus Covid-19 di wilayahnya. Analisis kebijakan yang akan diambil berasal berbagai macam disiplin ilmu dengan harapan bahwa dapat memberikan info-rmasi yang bersifat deskriptif, evaluatif, dan preskriptif.

\footnotetext{
${ }^{11}$ William N. Dunn, 2003, h. 100-101.
}

Analisis kebijakan menjawab tiga macam pertanyaan, yaitu: Pertama, nilai yang pencapaiannya merupakan tolak ukur utama untuk menilai apakah suatu masalah sudah teratasi?; Kedua, fakta yang keberadaanya dapat membatasi atau meningkatkan pencapaian nilai-nilai; Ketiga, tindakan yang penerapannya dapat menghasilkan pencapaian nilai-nilai.

Untuk menjawab analisis kebijakan dapat menggunakan salah satu atau kombinasi dari ketiga pendekatan analisis empiris, evaluatif dan normatif. Pendekatan tersebut dipaparkan dalam tabel sebagai berikut.

Tabel 1

Pendekatan Analisis Kebijakan

\begin{tabular}{|l|l|l|}
\hline Pendekatan & $\begin{array}{l}\text { Pertanyaan } \\
\text { Utama }\end{array}$ & $\begin{array}{c}\text { Tipe } \\
\text { Informasi }\end{array}$ \\
\hline Empiris & $\begin{array}{l}\text { Adakah dan } \\
\text { akankah } \\
\text { ada (fakta) }\end{array}$ & $\begin{array}{l}\text { Deskriptif } \\
\text { dan } \\
\text { Prediktif }\end{array}$ \\
\hline Normatif & $\begin{array}{l}\text { Apa } \\
\text { manfaatnya } \\
\text { (nilai) }\end{array}$ & Evaluatif \\
\hline Evaluatif & $\begin{array}{l}\text { Apakah } \\
\text { yang harus } \\
\text { diperbuat } \\
\text { (aksi) }\end{array}$ & Perspektif \\
\hline
\end{tabular}

Sumber : William N. Dunn, 2008 : 98.

Tabel di atas menjelaskan bahwa pendekatan empiris akan berbicara mengenai realitas-realitas kebijakan yang terjadi atau 
menerangkan dan menunjukkan faktafakta yang terjadi baik pada tahap implementasi dan atau evaluasi kebijakan. Realitas-realitas ini berupa fakta yang akan disajikan dalam bentuk deskriptif atau prediktif.

\section{Coronavirus Disease 2019}

Pada akhir Desember 2019, kita dikejutkan dengan adanya penemuan kasus pneumonia misterius pertama kali di Kota Wuhan, Provinsi Hubei, Republik Tiongkok. Menurut sumber terpercaya, mengatakan bahwa sumber penularan kasus ini belum diketahui pasti, tetapi kasus pertama dikaitkan dengan pasar ikan di Kota Wuhan. Pada rentang 18 - 29 Desember 2019, terdapat lima pasien yang dirawat dengan gejala gangguan prnafasan akut atau Acute Respiratory Distress Syndrome (ARDS). Kemudian, kasus ini terus mengalami peningkatan yang cukup signifikan, ditandai dengan dilaporkannya sebanyak 44 kasus. Penulran yang sangat cepat, penyakit ini akhirnya ditemukan pula di berbagai provinsi lain di Republik Tiongkok, Thailand, Jepang, dan Korea Selatan.

Para ahli kemudian meneliti sampel pasien dan menemukan etiologi atau ciri-ciri virus corona jenis baru. Pada awalnya kasus ini diberi nama 2019 novel coronavirus (2019-nCoV), kemudian pada 11 Februari 2020, diperbaharui oleh WHO dengan mengumumkan bahwa nama baru dari penyakit ini yakni Coronavirus Disease (Covid-19) yang disebabkan oleh virus Severe Acute Respiratory Syndrome Coronavirus-2 (SARS-CoV-2) .
Virus ini dapat ditularkan antar manusia dan telah menyebar secara luas di negar Tiongkok dan lebih dari 190 negara dan wilayah lainnya. Pada 12 Maret 2020, WHO mengumumkan Covid-19 sebagai penyakit pandemik. Update dari media per 30 Mei 2020, terdapat 5.819.962 kasus dan 362.786 jumlah kematian di seluruh dunia. Sementara di Indonesia sudah 25.773 di tetapkan kasus dengan positi Covid-19 dan 1.573 kasus kematian.

\section{METODE PENELITIAN}

Metode penelitian ini menggunakan metode penelitian deskriptif kualitatif. Penelitian ini berangkat dari permasalahan sosial, permasalahan yang ada di masyarakat dan berkembang setiap waktunya. Dengan metode kulatitaif maka penelitian ini akan bersifat fleksibel atau dapat beradaptasi dengan perubahanperubahan yang ada. ${ }^{12}$

Pengumpulan data penelitian ini menggunakan studi pustaka dan dokumentasi. Studi pustaka merupakan pengumpulan data yang bersumber pada buku-buku, literatur serta pada peraturan perundangundangan yang memiliki relevasi dengan topik tersebut. Sedangkan dokumentasi adalah pengambilan data yang diperoleh melalui dokumen-dokumen tertentu. Dokumen dapat berbentuk tulisan, misalnya catatan harian, sejarah kehidupan, cerita, biografi, peraturan serta

\footnotetext{
${ }^{12}$ Suharsimi Arikunto, Prosedur Penelitian: Suatu Pendekatan Praktik (Jakarta: Rineka Cipta, 2010), h. 3.
} 
kebijakan yang sesuai dan berkaitan dengan penelitian ini. ${ }^{13}$

\section{PEMBAHASAN}

\section{Kebijakan Jogo Tonggo}

Salah satu kebijakan Pemerintah Provinsi Jawa Tengah adalah kebijakan "Jogo Tonggo". Kebijakan Jogo Tonggo merupakan kebijakan percepatan penanganan Covid-19 yang berbasis masyarakat di tingkat Rumah Warga (RW), karena warga merupakan garda terdepan untuk melawan Covid-19. Pemerintah dan warga memiliki tanggung jawab dalam penanganan wabah Covid-19 ini. Maka, perlu adanya kerjasama antar pemerintah dengan warga. Sehingga wabah ini cepat teratasi.

Kebijakan Jogo Tonggo, memiliki 10 bidang struktur anggota diantaranya:

1. Karang Taruna

2. Dasa Wisma

3. Posyandu

4. Pendamping $\mathrm{PKH}$

5. PPL (Pertanian)

6. Pendamping Desa

7. Organisasi Lainnya

8. Warga

9. Bidan Desa

10. Linmas

Dari sepuluh bidang anggota tersebut, merekalah yang akan membantu pemerintah dalam penanganan Covid-19. Selain itu, Kebijakan Jogo Tonggo juga memiliki prinsip kerja, yaitu:

${ }^{13}$ Sugiono, Metode Penelitian Kualitatif (Bandung: Alfabeta, 2007), h. 138-140.
1. Kemanusiaan

2. Non Permanen, saat kondisi darurat

3. Gotong Royong

4. Transparan

5. Melibatkan semua pihak

Kebijakan Jogo Tonggo memiliki Sturktu Organisai, sebagai berikut:

Gambar 1

Struktur Organisasi Satgas Jogo Tonggo

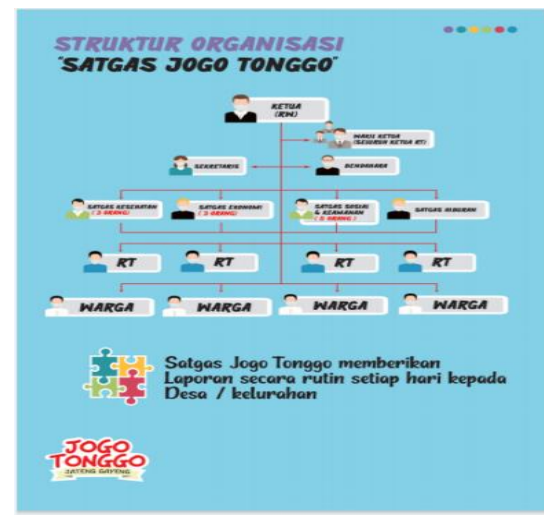

Sumber: Humas Jawa Tengah

Kebijakan Jogo Tonggo memiliki bidang tugas sebagai berikut:

1. Bidang Kesehatan

a. Mendata setiap orang yang keluar masuk desa.

b. Mencegah penyebaran dan penularan Covd-19 dengan membawa orang yang teridentifikasi PDP ke rumah sakit rujukan.

c. Memastikan dan update data siaa saja yang berstatus OTG, ODP dan PDP.

d. Mengupayakan ODP dan OTG karantina mandiri 14 hari. 
e. Memastikan lokasi strategis tersedia cuci tangan, penyemprotan disinfektan secararutin, warga tertib keluar rumah memakai masker, jaga jarak antara warga 1,5-2 meter.

f. Memberikan pelayanan kesehatan: pemeriksaan suhu badan, pengecekan gejala Covid-19, pengecekan tempat cuci tangan.

g. Mendorong praktek hidup bersih dan sehat, makan minum seimbang, olahraga, mandi teratur, istirahat cukup, lingkungan bersih.

h. Berkoordinasi dengan petugas kesehatan desa untuk pemeriksaan lanjut jika ada kondisi darurat.

2. Bidang Ekonomi

a. Mendata kebutuhan dasar masyarakat.

b. Mendata warga yang tidak mampu, menyediakan kebutuhan dasar.

c. Mengupayakan secara maksimal agar warga bisa dibantu.

d. Memastikan bantuan tepat sasaran

e. Memastikan kegiatan bertani, berkebun dan berdagang tetap berjalan dengan memperhatikan protokol kesehatan.

f. Melayani kebutuhan makan seharihari warga yang karantina mandiri

g. Mendorong terbangunnya lumbung pangan.

3. Bidang Sosial \& Keamanan

a. Bersama tim kesehatan melakukan pencatatan orang masuk dan keluar di lingkungan RW.

b. Membuat jadwal giliran ronda. c. Menghindari kerumunan.

d. Memastikan yang berstatus ODP dan OTG untuk tidak keluar rumah.

e. Menyiapkandata pilah penerima bantuan agar seluruh bantuan tepat sasaran dan tepat guna.

f. Memastikan kelompok lansia, difabel, ibu hamil serta anak-anak mendapatkan perlindungan.

g. Memastikan seluruh kegiatan sosial dilakukan secara gotong royong.

h. Meredam dan menyelesaikan konflik sosial secara rembungan/ musyawarah.

i. Memastikan kesepakatan warga terkait dengan jam berkunjung/ bertamu.

j. Memastikan setiap rumah memiliki alat komunikasi umum manual.

k. Memberikan pemahaman bahwa jenazah tidak menularkan Covid19.

1. Pengamanan warung - warung sembako.

\section{Bidang Hiburan}

Untuk mengurangi kejenuhan, warga dapat melaksanakan hiburan mandiri, sesuai kearifan lokal masing-masing.

Kebijakan Jogo Tonggo juga memberikan laporan secara rutin setiap hari kepada desa/kelurahan, seperti: warga yang dirawat di rumah sakit, warga yang sembuh dari perawatan, warga yang sudah dan belum mendapatkan bantuan, wraga yang melakukan karantina mandiri 14 hari, ketersediaan sembilan bahan pokok, jam 
kunjung warga/tamu, jadwal patrol ronda, informasi penting lainnya.

\section{Analisis Kebijakan Jogo Tonggo}

Pemerintah Jawa Tengah telah mengeluarkan salah satu kebijakan untuk penanganan Covid-19 yaitu kebijakan Jogo Tonggo. Istilah Jogo Tonggo diambil dari bahasa jawa. 'Jogo' artinya menjaga, sedangkan 'Tonggo' artinya tetangga. Kebijakan Jogo Tonggo ini mulai diberlakukan pada tanggal 25 April 2020. Sejak pembentukannya hingga saat ini wabah Covid-19 masih terus mengalami angka kenaikan. Pemerintah perlu mendapatkan informasi terkait gambaran dan evaluasi terkait kebijakan yang telah dikeluarkan. Gambaran dan evaluasi yang dilakukan dapat dijadikan sebagai bahan pertimbangan untuk memilih tindakan atau alternatif kebijakan yang dapat dilakukan untuk mengatasi masalah wabah Covid-19 ini.

Analisis kebijakan dilakukan sebagai proses dalam memproduksi dan mentrasnformasi pengetahuan dan informasi yang relevan dengan kebijakan pemerintah yang sudah ada. Melalui analisis kebijakan, seorang analis dapat menghasilkan informasi dan argumentasi terhadap kebijakan tersebut. Dengan menganalisis kebijakan yang telah dikeluarkan oleh Pemerintah Jawa Tengah dalam penanganan Covid-19, maka seorang analis akan mendapatkan jawaban atas tiga pertanyaan. Pertanyaan yang dapat dijawab melalui analisis kebijakan menurut Dunn adalah dengan melihat fakta, nilai dan tindakan dari kebijakan penanganan Covid-19 yang dilakukan oleh pemerintah. Adapun fakta, nilai dan tindakan tentang kebijakan Jogo Tonggo dalam penanganan wabah Covid19 adalah sebagai berikut.

\section{Fakta Kebijakan Jogo Tonggo}

Fakta merupakan realitas atau empiris untuk menjelaskan sebab dan akibat dari suatu kebijakan. Fakta yang menjelaskan kenyataan yang terjadi dilapangan, baik yang keberadaannya dapat meningktakan atau membatasi pencapaian tujuan dari sebuah kebijakan. Fakta yang terjadi di lapangan dapat dijadikan sebagai dasar untuk menilai apakah kebijakan yang telah dikeluarkan telah berhasil atau tidak.

Pemerintah telah mengeluarkan salah satu kebijakan yaitu Jogo Tonggo untuk menangani wabah Covid-19 yang ada di Jawa Tengah. Kebijakan ini melibatkan banyak elemen seperti lembaga, organisasi dan masyarakat itu sendiri. Keterlibatan masyarakat dalam penanganan wabah Covid-19 sangat baik, selain untuk mengedukasi masyarakat juga mengajak masyarakat untuk berperan aktif.

Kebijakan yang berjalan lebih dari sebulan ini, belum membuahkan hasil yang baik. Penambahan kasus positif Covid-19 di Jawa Tengah masih terus bertambah dan menduduki urutan ke-5 dari 34 provinsi. Kebijakan Jogo Tonggo belum sepenuhnya berjalan baik di lapangan. Edukasi yang telah disosialisasikan pemerintah kepada masyarakat masih banyak yang menghiraukan, seperti berkerumun, tidak memakai masker ketika keluar rumah dan sebagainya. Ketika mendekati hari lebaran, masih banyak 
masyarakat keluar rumah untuk belanja kebutuhan lebaran. Masih banyaknya masyarkat yang kurang sadar akan bahaya dari wabah Covid-19 ini, menandakan bahwa masih kurangnya sosialisasi kepada masyarakat.

Tidak semua daerah memiliki anggota Joko Tonggo yang lengkap. Salah satunya karang taruna, beberapa daerah di Jawa Tengah tidak memiliki karang taruna, baik itu karena kurang aktif atau bahkan pasif. Sehingga akan menghambat keaktifan dari kebijakan Jogo Tonggo itu sendiri.

\section{Nilai yang Dicapai dari Kebijakan Jogo}

\section{Tonggo}

Setelah mendapatkan gambaran atau deskripsi fakta di lapangan tentang Kebijakan Joko Tonggo sebagai penanggulangan Covid-19 di Jawa Tengah, maka langkah selanjutnya adalah menilai pencapaian fakta tersebut. Nilai atau evaluasi yang dilakukan, menunjuk pada hasil dari kebijakan atau program yang telah dilakukan pemerintah dalam penanganan Covid-19 ini. Sehingga dapat dikatakan bahwa evaluasi adalah proses untuk melihat apakah kebijakan yang dikeluarkan dapat mengatasi permasalahan atau tidak.

Pencegahan memiliki tujuan mencegah segala bentuk wabah Covid-19 untuk menyebar lebih luas di masyarakat. Upaya pencegahan yang dilakukan melalui media sosial. Dalam hal ini pemerintah sebagai lembaga yang memiliki wewenang seharusnya mampu untuk memberikan pemahaman yang sama baik kepada masyarakat maupun kepada sesama anggota Jogo Tonggo dalam upaya penanganan wabah Covid-19. Karena hingga saat ini masih banyak masyarakat yang belum sadar betu akan wabah Covid19 ini.

\section{Tindakan dalam Kebijakan Jogo Tonggo}

Pemerintah belum berhasil untuk melakukan penanganan wabah Covid-19. Hal ini dikarenakan kelemahan pelaksana kebijakan dalam mengimplementasi kebijakan tersebut, hal-hal yang dapat dilakukan pemerintah untuk meningkatkan pencapaian nilai/tujuan tersebut adalah:

\section{Kualitas Sumber Daya Pelaksana}

Pemerintah harus memberikan pemahaman yang merata kepada seluruh jajaran pelaksana kebijakan yang dalam hal ini adalah anggota Jogo Tonggo. Pemahaman yang diberikan terkait dengan penanganan wabah Covid-19, selain itu pemahaman terhadap hak, kewajiban, tugas, dan fungsi yang dimiliki oleh masing-masing anggota Jogo Tonggo. Sehingga diharapkan anggota Jogo Tonggo mengetahui apa yang dapat dilakukan untuk menangani wabah Covid-19 di Jawa Tengah.

\section{Adanya Evaluasi}

Perlu dipahami bahwa evaluasi bukan hanya sekedar pemberian laporan rutin terkait jumlah korban, namun substansi dari evaluasi adalah setiap bidang terkait mampu mengkomunikasikan kekurangan atau kelebihan terhadap kinerjanya dan kinerja bidang yang lain. 


\section{Pemilihan Media Sosialisasi}

Sosialisasi belum dilaksanakan secara massif, oleh karenanya pemerintah dapat menggunakan media cetak atau elektronik untuk membantu dalam mensosialissikan kepada masyarakat, terutama masyarakat yang berada di pelosok daerah yang jauh dari jangkauan.

\section{PENUTUP}

Berdasarkan hasil penelitian, pembahasan dan analisis terhadap kebijakan Jogo Tonggo dalam penanganan wabah Covid19 di Provinsi Jawa Tengah, maka kami mengambil kesimpulan bahwa pertama, fakta dilapangan menunjukkan bahwa pemerintah telah mengeluarkan kebijakan sebagai sikap untuk penanganan wabah Covid-19 di Jawa Tengah. Seperti kebijakan Jogo Tonggo, yang melibatkan banyak elemen lembaga, organisasi, instansi, dan masyarkat itu sendiri. Kedua, pelaksanaan kebijakan Jogo Tonggo belum maksimal. Terlihat, masih banyak masyarakat yang kurang sadar akan bahwa Covid-19, masih banyak yang menghiraukan himbauan pemerintah, seperti stay at home.

Ketiga, pemerintah belum bisa meminimalisir angka kenaikan kasus Covid-19. Selain, permasalahan yang hubungannya dengan sasaran utama kebijakan (masyarakat), permasalahan juga timbul pada tingkat pelaksana kebijakan. Keempat, apa yang seharusnya dilakukan oleh pemerintah untuk kebijakan Jogo Tonggo dalam menangani wabah Covid-19 adalah dengan anggota
Jogo Tonggo mengetahui apa yang menjadi hak, kewajiban, tugas dan fungsi yang dimiliki. Sehingga mereka mengetahui apa yang harus dilakukan. Kelima, adanya evaluasi dan pemilihan media sosial, menjadi alat bantu untuk melengkapi kekuarangan kebijakan Jogo Tonggo saat ini.

\section{DAFTAR PUSTAKA}

Abdullah Ramdhani \& Muhammad Ali Ramdhani, "Konsep Umum dalam Pelaksanaan Kebijakan Publik", Jurnal Publik, Vol. 11, No. 01 (2017), h. 1-12.

Budi Winarno, Kebijakan Publik: Teori dan Proses (Jakarta: Media Pressindo, 2007).

Nur Rohim Yunus \& Annisa Rezki, "Kebijakan Pemberlakuan Lockdown sebagai Antisipasi dalam Penyebaran Corona Virus Covid-19", Salam: Jurnal Sosial dan Budaya Syar-i, Vol. Vol. 7 No. 3 (2020), h. 227-238.

Riant Nugroho, Public Policy (Jakarta: PT Elex Media Komputindo, 2009).

Sugiono, Metode Penelitian Kualitatif (Bandung: Alfabeta, 2007).

Suharsimi Arikunto, Prosedur Penelitian: Suatu Pendekatan Praktik (Jakarta: Rineka Cipta, 2010).

William N. Dunn, Analisis Kebijakan Publik (Yogyakarta: Gajah Mada University Press, 2003). 


\section{Website}

Gugus Tugas Percepatan Penanganan Covid-19. "Data Sebaran" dalam https://covid19.go.id/ diakses 31 Mei 2020.

Luki Sandra Amalia, "Menanti Kebijakan Ketahanan Pangan di Tengah Pandemi Covid-19" dalam http://www.politik.lipi.go.id/kolom / kolom-2/politik-nasional/1397menanti-kebijakan-ketahananpangan-di-tengah-pandemi-Covid19 di-akses 30 Mei 2020.

Provinsi Jawa Tengah, "Sebaran Kasus COVID-19 Di Jawa Tengah" dalam https://corona. jatengprov.go.id/ diakses $30 \mathrm{Mei}$ 2020. 